\title{
POWSTANIE REPUBLIKI CZECHOSLOWACKIEJ PO I WOJNIE ŚWIATOWEJ I ZNACZENIE REWOLUCYJNEGO ZGROMADZENIA NARODOWEGO W TYM PROCESIE
}

\author{
THE REVOLUTIONARY NATIONAL ASSEMBLY AND ITS ROLE \\ IN ESTABLISHING THE FIRST CZECHOSLOVAK REPUBLIC \\ AFTER THE FIRST WORLD WAR
}

Soon after the First World War broke out in 1914, both in the country and abroad a movement was formed aimed at establishing an independent Czecho-Slovak state. It was hoped that Austria-Hungary would collapse and Germany be defeated. To reach its goal, the independence movement had to obtain the support of Czechs and Slovaks abroad, mainly in the USA, France and Russia, as well as benevolence of the Entente Powers. Initially, the decisive influence of Russia was taken into consideration, which resulted in the postulate to preserve monarchy. As Russia's position was weakening, the Czecho-Slovak resistance movement became more oriented towards Entente's western powers and gradually, especially abroad, emphasized the vision of the future state as a republic and its democratic system. In order to understand the establishment of the Revolutionary National Assembly in Prague in 1918, the origin of its founding must be presented and a reference made to Austro-Hungarian parliamentarism. On 19 November 1916 information was published on founding the Czech Union comprising Deputies of the Austrian Parliament - the Imperial Council (Reichsrat) in Vienna. It was a group of Deputies of nine political parties, who committed themselves to act in accordance with the principle of majority in national-political and constitutional-legal matters. Simultaneously, the National Committee was founded as a permanent body associating representatives of Czech political parties. It was to support the Czech Union as the highest authority in those matters of political life that transgressed competences of Deputies to the parliament. Initially, the Czech Union was loyal to the Austrian government and even distanced itself from the Czecho-Slovak resistance movement abroad. Among the Czechs important organizational elements were established, which contributed to the creation of the union and became a catalyst of the Czech political life.

Słowa kluczowe: czecho-słowacki ruch oporu w kraju i za granicą, rozpad Austro-Węgier, powstanie Czechosłowacji, Czechosłowacki Komitet Narodowy, Rewolucyjne Zgromadzenie Narodowe, Słowacka Rada Narodowa, konstytucja tymczasowa

Key words: Czecho-Slovak domestic and foreign resistance, break-up of Austro-Hungarian Empire, formation of Czecho-Slovakia, Czechoslovak National Committee, Revolutionary National Assembly, Slovak National Council, temporary constitution

* Prof. PhDr. Róbert Letz, Univerzita Komenského v Bratislave UK, Pedagogická fakulta, Katedra histórie, letz@fedu.uniba.sk, https://orcid.org/0000-0003-1731-9205 


\section{UWAGI WSTĘPNE}

Kótko po rozpoczęciu I wojny światowej w 1914 r. w kraju i za granicą kształI tował się ruch, którego celem było powstanie niepodległego państwa czecho-słowackiego. Liczono na porażkę i rozbicie Austro-Węgier oraz na klęskę Niemiec. Aby osiągnąć ten cel, ruch niepodległościowy musiał pozyskać wsparcie Czechów i Słowaków za granicą, przede wszystkim w USA, Francji i Rosji oraz życzliwość mocarstw ententy. Początkowo liczono się z decydującym wpływem Rosji, z czego wynikał też postulat zachowania monarchii. Wraz z osłabieniem pozycji Rosji czecho-słowacki ruch oporu orientował się bardziej na zachodnie mocarstwa ententy i stopniowo — zwłaszcza za granicą — podkreślał wizję przyszłego państwa jako republiki oraz jego demokratyczny ustrój.

W celu zrozumienia powstania Rewolucyjnego Zgromadzenia Narodowego w Pradze w 1918 r. konieczne jest przedstawienie genezy jego powstania i odniesienie się parlamentaryzmu austro-węgierskiego. 19 listopada 1916 r. opublikowano informację o utworzeniu Związku Czeskiego składającego się z posłów parlamentu austriackiego — Rady Państwa (Reichsrat) w Wiedniu. Była to grupa posłów z dziewięciu partii politycznych, którzy zobowiązali się postępować zgodnie z zasadą większości w kwestiach narodowo-politycznych i konstytucyjnoprawnych. Jednocześnie ze Związkiem Czeskim powstał Komitet Narodowy jako stałe gremium zrzeszające przedstawicieli czeskich partii politycznych. Miał on stanowić wsparcie dla Związku Czeskiego jako najwyższy autorytet w tych kwestiach życia politycznego, które wykraczały poza kompetencje posłów parlamentu. Wskutek stworzenia Związku Czeskiego środek ciężkości polityki czeskiej przeniósł się z partii młodoczechów na partię agrarną i socjaldemokratyczną. Początkowo Związek Czeski był wobec rządu austriackiego lojalny, a nawet dystansował się od czecho-słowackiego ruchu oporu za granicą ${ }^{1}$. W środowisku czeskim powstały ważne elementy organizacyjne, które przyczyniły się do zjednoczenia i stały się katalizatorem czeskiego życia politycznego.

\section{SYTUACJA W AUSTRO-WËGRZECH I OŻYWIENIE ŻYCIA POLITYCZNEGO W 1917 R.}

Istotną zmianę w Austro-Węgrzech spowodowała śmierć władcy Franciszka Józefa I 21 listopada 1916 r. Jego następcą został Karol (Karol I jako cesarz Austrii oraz Karol IV jako król Węgier). Objęcie rządów przez nowego cesarza było postrzegane przez premiera Węgier Istvána Tiszę jako zagrożenie dla dotychczasowej pozycji oraz sytuacji wewnętrznej Węgier, dlatego naciskał na Karola, aby ten jak najszybciej koronował się na króla Węgier. Koronacja Karola i jego małżonki odbyła się w Budapeszcie 30 grudnia 1916 r. W ten sposób Karol znalazł się w ścisłych ramach polityki dualistycznej. W przysiędze koronacyjnej zobowiązał się on do ochrony integralności Węgier, a w istocie stracił wpływ na wydarzenia na Węgrzech. Działania nowego władcy w zakresie polityki krajowej i międzynarodowej budziły sympatię. Już w marcu $1917 \mathrm{r}$.

\footnotetext{
${ }^{1}$ R. Kvaček, První světová válka a česká otázka, Praha 2013, s. 88.
} 
cesarz zdymisjonował szefa Sztabu Generalnego Armii Austro-Węgier Konráda von Hötzendorfa, zwolennika zachowania kursu wojennego. Karol zdawał sobie sprawę, że katastrofalna sytuacja ekonomiczna, wyczerpanie wojną oraz nasilające się napięcia społeczne mogą doprowadzić do niepokojów społecznych i rozpadu cesarstwa. Rozwiązanie dostrzegał w stopniowym łagodzeniu środków represji, a następnie w zawarciu odrębnego traktatu pokojowego. Pojawiła się też kwestia federalizacji monarchii. Próbując załagodzić napięcia społeczne, w lipcu 1917 r. Karol ogłosił amnestię. Zwolniono 2593 osoby skazane z powodów politycznych, które pochodziły ze wszystkich narodów monarchii ${ }^{2}$. Dzięki temu wyszli na wolność także ważni politycy czescy: Karel Kramář i Alois Rašín, których skazano na wysokie kary w procesie ,zdrajców stanu” w 1916 r. Karol, który dążył do zawarcia odrębnego pokoju, podjął próbę przeprowadzenia tajnych rozmów pokojowych z Francją bez wiedzy Niemiec (tzw. afera Sykstusa). Wyszły one jednak na jaw i Austro-Węgry praktycznie aż do końca musiały prowadzić lojalną politykę wobec Niemiec.

Kiedy cesarz po trzech latach zwołał na 30 maja 1917 r. Radę Państwa w Wiedniu, czeski pisarz Jaroslav Kvapil przygotował apel czeskich pisarzy skierowany do czeskich posłów w Radzie Państwa. Finalnie podpisało się pod nim 222 autorów. Sygnatariusze apelu jednoznacznie opowiedzieli się za wprowadzeniem demokratycznych praw obywatelskich i powstrzymaniem represji oraz zaapelowali do posłów czeskich, aby bronili w parlamencie interesów czeskiego narodu. W przeciwnym razie powinni oni zrezygnować z mandatów. W dokumencie zawarto fragment dotyczący optyki czecho-słowackiej: ,,Te dążenia i prawa narodu czechosłowackiego zyskują nową energię oraz dynamikę, dzięki dotychczasowemu przebiegowi wojny, w trakcie której przyszła Europa nabiera nowego, demokratycznego charakteru, a wszelka nasza polityka musi mieć równie wielki wyzwoleńczy charakter” 3 . Termin ,naród czechosłowacki” został użyty obok terminu ,naród czeski”. Czescy posłowie zostali nawet nazwani rzecznikami „narodu czechosłowackiego". To świadczy o czecho-słowackiej orientacji polityki czeskiej. To, że ten motyw pojawił się w apelu, jest zasługą przede wszystkim Słowaka, lekarza Vavro Šrobára, który właśnie w kwietniu 1917 r. przyjechał do Pragi przez Budapeszt i Wiedeń. Šrobár rozmawiał z Kvapilem i innymi działaczami czeskimi o tym, aby w apelu pisarzy oraz w przygotowywanym oświadczeniu posłów Związku Czeskiego znalazła się stosowna wzmianka ${ }^{4}$.

Krótko przed rozpoczęciem posiedzenia wiedeńskiego parlamentu w Pradze i Wiedniu odbył się bój w sprawie treści oświadczenia posłów czeskich. Šrobár oraz redaktor Anton Štefánek, którzy przebywali wówczas w Pradze, dołożyli wszelkich starań, aby w oświadczeniu wspomniano o Słowacji. Šrobár otrzymał nawet pozytywną opinię w kwestii włączenia Słowacji do programu czeskiego od przebywających jeszcze w więzieniu Kramářa i Rašína. Jeśli Šrobár i Štefánek naciskali na polityków czeskich obecnych w Pradze, to Milan Hodža, Ivan Dérer oraz Kornel Stodola przekonywali

\footnotetext{
${ }^{2}$ H. Rieder, Kaiser Karl, München 1981, s. 163.

${ }^{3}$ F. Soukup, 28. ř́jen 1918, t. 1, Praha 1928, s. 397.

${ }^{4}$ V. Šrobár, Osvobodené Slovensko. Pamäti z rokov 1918-1920, t. 1, Praha 1928, s. 105.
} 
czeskich polityków bezpośrednio w Wiedniu. Z różnych propozycji przygotowywanego oświadczenia czeskich posłów podczas wspólnego posiedzenia Komitetu Narodowego i prezydium Związku Czeskiego został ostatecznie przyjęty projekt przewodniczącego partii agrarnej Antonína Švehli. Została w nim uwzględniona także Słowacja. Oświadczenie posłów czeskich podczas posiedzenia parlamentu w Wiedniu 30 maja 1917 r. wygłosił przewodniczący Związku Czeskiego František Staněk. Posłowie odrzucili w nim model dualistyczny i wskazywali na konieczność przekształcenia monarchii w państwo związkowe wolnych i równoprawnych państw narodowych. Jednocześnie opowiedzieli się za prawem narodu do samostanowienia: „Opierając się w tej historycznej chwili na naturalnym prawie narodów do samostanowienia oraz swobodnego rozwoju, co dodatkowo potęgują nasze niezaprzeczalne, historyczne prawa, w pełni uznane w aktach państwowych, w imieniu swojego ludu będziemy domagać się połączenia wszystkich szczepów narodu czechosłowiańskiego w państwo demokratyczne, przy czym nie da się pominąć także szczepu czechosłowiańskiego zamieszkującego zwarcie w historycznych granicach naszej czeskiej ojczyzny" . W tym ambitnym oświadczeniu publicznie zadeklarowano zainteresowanie — z prawnopaństwowego punktu widzenia - Słowakami żyjącymi na Węgrzech.

Następnie kilku wybitnym czeskim prawnikom powierzono opracowanie projektów konstytucji państwa czeskiego. Ich wizją było przekształcenie monarchii habsburskiej w federację państw narodowych, zjednoczonych — przez osobę władcy - w unię personalną. Od idei „czeskiego państwa” ze Słowacją w ramach przebudowanej monarchii austro-węgierskiej był tylko mały krok do stworzenia niepodległego państwa czecho-słowackiego. Dążenie ruchu oporu za granicą do przeforsowania tej koncepcji było przecież w kraju znane. Oświadczenie posłów Związku Czeskiego zainspirowało też posłów innych narodowości niż niemiecka w parlamencie wiedeńskim do przygotowania swoich deklaracji. W podobny sposób wypowiadali się Słoweńcy, Polacy i Ukraińcy. Oświadczenie posłów czeskich przekierowywało ówczesną politykę na nowe tory. Politycy austriaccy nie byli na to przygotowani, dlatego albo energicznie odrzucali nowe idee (posłowie niemieccy w parlamencie wiedeńskim), albo zdobywali się tylko na wyrażanie ogólnego stanowiska (mowa tronowa Karola z 31 maja 1917 r. o stworzeniu warunków do swobodnego rozwoju narodowego i kulturalnego narodów). Umieszczenie w polu widzenia czeskiej polityki Słowacji miało dalekosiężne skutki. Pojawiło się jednak pytanie, czy nie są to tylko pozorne deklaracje i emocjonalne utożsamianie się ze Słowacją bez jej wewnętrznego poznania. „Nikt jednak nie zdawał sobie w pełni sprawy ze skomplikowania problemu słowackiego, nie zastanawiał się nad prawnopaństwowym położeniem Słowacji w państwie czecho-słowackim, nie zastanawiał się nad problemami wynikającymi z różnic gospodarczych, społecznych, mentalnych, religijnych itd." 6

Oświadczenie czeskich posłów w austriackiej części monarchii zadziałało jak zapalnik, ale jeszcze większy odzew przyniosło na Węgrzech. Miejscowa prasa pisała o tym,

${ }^{5}$ Stenographisches Protokoll. Haus der Abgeordneten, XXII. Session. 1. (Eröffnungs-) Sitzung. Mittwoch, den 30. Mai 1917, s. 34.

${ }_{6}^{6}$ J. Galandauer, Vznik Československé republiky 1918, Praha, 1988, s. 176. 
że podczas gdy Węgrzy wykrwawiają się na froncie i ratują Austrię, Czesi chcą zrabować piękną perłę z korony św. Stefana i odebrać Węgrom spory kawałek terytorium. Premier Węgier István Tisza napisał 1 czerwca 1917 r. list protestacyjny do premiera Austrii Heinricha H. Clam-Martinica, w którym domagał się, aby ten odrzucił w imieniu rządu austriackiego ,niesłychanie bezczelne oświadczenie Czechów” wymierzone w integralność Węgier. Tisza protestował też w węgierskim parlamencie. Według Tiszy takie oświadczenia oznaczały ingerowanie w sprawy Węgier. Zalecał on, żeby nie lekceważyć ich szkodliwego oddziaływania i protestować przeciwko każdej inicjatywie naruszajacej integralność terytorialną państwa. Tisza przekonywał, że cała sprawa stanowi dowód na słabość austriackiej części państwa ${ }^{7}$. Austriacki premier Clam-Martinic zareagował na oświadczenia narodowościowe w parlamencie 13 czerwca 1917, ptotestując przeciwko ingerowaniu w suwerenność mocarstw centralnych czy też niezależność drugiego państwa monarchii - Węgier. Czescy, słoweńscy, ukraińscy i polscy posłowie pozostali jednak przy swoim stanowisku.

Wiosna i lato 1917 r. przyniosły ożywienie w polityce w całych Austro-Węgrzech. Nie chodziło tylko o deklaracje i oświadczenia, wiele działań podejmowano w ukryciu. Ożywiła swoją działalność tajna organizacja czeskiego ruchu niepodległościowego „Mafia” (Maffia), która funkcjonowała od 1914 r. Liczyła ona około 200 członków, zdobywała cenne informacje wywiadowcze i utrzymywała kontakt z przedstawicielami ruchów niepodległościowych za granicą. W jej kierownictwie działali: E. Beneš, K. Kramář, A. Rašín i J. Scheiner. Duszą całej „Mafii” był adwokat Přemysl Šámal, organizacja sondowała poglądy, wybierała odpowiednich ludzi. W tym czasie Wiedeń stał się ważnym miejscem kontaktowym dla słowackich polityków, którzy odbywali tam służbę wojskową. M. Hodža, K. Stodola, I. Dérer, J. Cablk stworzyli tajną organizację, nazywaną przez niektórych słowacką „Mafią” na wzór czeskiej. W spotkaniach słowackiej organizacji uczestniczył też czeski urzędnik bankowy i działacz towarzystwa Československá jednota (Jedność Czechosłowacka) Rudolf Pilát oraz katolicki ksiądz z Moraw Alois Kolísek. Członkowie towarzystwa dyskutowali w Wiedniu o aktualnych zagadnieniach politycznych, byli ważnym źródłem informacji o Słowacji dla polityków czeskich, zwłaszcza posłów w Wiedniu, podtrzymywali też słowackie kontakty z przedstawicielami innych narodów monarchii, szczególnie z Rumunami, Słoweńcami i Chorwatami. A. Kolísek w lipcu 1917 r. został wysłany do Ružomberka, aby pozyskać dla idei czecho-słowackiej konserwatywnego przywódcę katolickich Słowaków, miejscowego proboszcza Andreja Hlinkę, co zakończyło się powodzeniem ${ }^{8}$.

Gorącą atmosferę podgrzały jeszcze wiadomości o nowej rewolucji bolszewickiej w Rosji. Oświadczenia rządu bolszewików w sprawie zawarcia natychmiastowego pokoju, podziału ziemi wśród rolników oraz realizacji prawa narodów do samostanowienia były bardzo atrakcyjne i miały wpływ na poglądy i postępowanie polityków oraz szerokich warstw społecznych monarchii austro-węgierskiej. 22 grudnia 1917 r. w Brześciu

7 Országgyűlés képviselőházának naplója. XXXVI. kötét. 726. országos ülés 1917 június 21-én, csütörtökön. Budapest: Hiteles kiadás, 1917, s. 19.

${ }^{8}$ A. Kolísek, S Andrejom, „Rozvoj” 1924, nr 1-2, s. 25. 
Litewskim przedstawiciele Rosji Radzieckiej i mocarstwa centralne rozpoczęły rozmowy pokojowe. Austro-Węgry reprezentował minister spraw zagranicznych Ottokar Czernin. Sowiecka Rosja jako warunek pokoju przedstawiła postulat, aby przyjęto zasadę, że narodom, które przed wojną nie były niepodległe, zostanie zagwarantowana możliwość podjęcia $\mathrm{w}$ referendum decyzji $\mathrm{w}$ sprawie swojej przynależności do państwa, w skład którego wchodziły, albo o swojej niezależności. Prawa mniejszości narodowych miało być chronione, a tam, gdzie to byłoby możliwe, także w formie autonomicznej administracji. Na to w imieniu mocarstw centralnych odpowiedział Czernin, który odrzucił rosyjski postulat z uzasadnieniem, że kwestia przynależności państwowej narodów, które nie mają niezależności państwowej, nie może być regulowana według stanowiska mocarstw centralnych na poziomie międzypaństwowym. Może zostać rozwiązana przez państwo, którego to dotyczy, w formie porozumienia z narodami na drodze konstytucyjnej. Stanowisko Czernina po opublikowaniu wywołało protesty przedstawicieli narodowości nieniemieckich w austriackiej części monarchii. Przedstawiciele Związku Czeskiego próbowali wyrazić sprzeciw w parlamencie wiedeńskim, ale próba zwołania nadzwyczajnego posiedzenia tego gremium zakończyła się niepowodzeniem. Przygotowano więc zastępczą akcję na święto Trzech Króli. 6 stycznia 1918 r. zwołano w Pradze spotkanie wszystkich czeskich posłów do Rady Państwa w Wiedniu oraz czeskich posłów z trzech rozwiązanych sejmów krajowych: czeskiego, morawskiego i śląskiego. Ten ,parlament generalny” wszystkich posłów czeskich zebrał się w Domu Miejskim w Pradze, gdzie została ogłoszona deklaracja i to nie tylko w imieniu „ludu czeskiego", ale także ,przemilczanej gałęzi słowackiej na Węgrzech”. W deklaracji odrzucono stanowisko Czernina w kwestii prawa do samostanowienia, zaprezentowane w Brześciu Litewskim. Polemizowano z nim w zakresie możliwości realizowania tego prawa w Austro-Węgrzech na drodze konstytucyjnej. W dokumencie zawarto też wizję przyszłego państwa czecho-słowackiego. Miało to być państwo suwerenne, demokratyczne, sprawiedliwe społecznie, zbudowane na zasadzie równości wszystkich obywateli. To państwo miało samodzielnie wziąc udział w przyszłej konferencji pokojowej9. Znaczenie deklaracji dnia Trzech Króli polega na tym, że zapowiadane publicznie cele wewnętrznej polityki czeskiej łączono z celami czecho-słowackiego ruchu oporu za granicą. Nie chodziło już o rozwiązanie kwestii państwa czecho-słowackiego w warunkach konstytucyjnych Austro-Węgier, ale o dążenie do osiągnięcia własnej niezależności państwowej i jej międzynarodowe uznanie. Tekst deklaracji został skonfiskowany przez rząd austriacki, który jednak po protestach wycofał się z tej decyzji.

\section{AKTYWIZACJA SLOWAKÓW NA WIOSNE 1918 R. ORAZ POWSTANIE CZECHOSLOWACKIEGO KOMITETU NARODOWEGO}

W maju 1918 r. uaktywnili się Słowacy. Na zgromadzeniu robotników 1 maja 1918 r. w Liptowskim Mikulaszu przyjęto rezolucję, w której — oprócz pokoju i postulatów społecznych — domagano się respektowania prawa narodów do samostanowienia, także

\footnotetext{
9 J. Galandauer, Vznik Československé republiky..., s. 294-296.
} 
dla „węgierskiej gałęzi szczepu czechosłowackiego". Było to pierwsze publiczne wystąpienie na Słowacji podczas wojny na rzecz wspólnoty czecho-słowackiej. Przewodniczący Słowackiej Partii Narodowej (Slovenská národná strana, dalej: SNS) Matúš Dula zwołał poufną naradę roboczą ścisłego kierownictwa partii na 24 maja $1918 \mathrm{r}$. w mieście Turčiansky Sv. Martin. Uczsetnicy narady byli niezdecydowani w kwestii tego, czy iść dalej z Węgrami, czy z Czechami. Głos zabrał A. Hlinka, który oświadczył, że „Habsburgowie byli odwiecznymi nieprzyjaciółmi naszego narodu i Słowiańszczyzny. Bez podjęcia decyzji nigdy nie osiągniemy upragnionego celu. Nadszedł czas czynów. Z pewnością musimy określić, czy pójdziemy dalej z Węgrami, czy z Czechami. Nie omijajmy tej kwestii, powiedzmy otwarcie, że jesteśmy za orientacją czecho-słowacką. Tysiącletnie małżeństwo z Węgrami się nie udało. Musimy się rozstać” ${ }^{10}$. Na zakończenie narady przyjęto jasne stanowisko, w którym poparto opcję czecho-słowacką: „Słowacka Partia Narodowa stoi na stanowisku bezwarunkowego i niepodlegającego ograniczeniom prawa narodu słowackiego do samostanowienia i na tej podstawie domaga się dla narodu słowackiego udziału w stworzeniu niepodległego państwa składającego się ze Słowacji, Czech, Moraw i Śląska" ${ }^{11}$. Dulę upoważniono do przekazania Czechom tej ostatecznej decyzji. Natomiast rezultat tego kluczowego spotkania był władzom węgierskim nieznany.

Wypowiedź ministra spraw zagranicznych Austro-Węgier Czernina o posłach czeskich, że są oni zdrajcami państwa i przedłużają wojnę, wywołała silne emocje. W Domu Miejskim w Pradze 13 kwietnia 1918 r. odbyło się zgromadzenie narodowe, w którym wzięły udział wszystkie warstwy czeskiego społeczeństwa. Była obecna inteligencja, posłowie Rady Państwa i sejmów krajowych, przedstawiciele wszystkich czeskich partii politycznych, instytucji naukowych, rzemieślników, rolników i robotników. Wystąpił na nim przewodniczący Związku Czeskiego František Staněk, który podkreślił, że tym, kto przedłuża wojnę, nie jest naród czeski, ale te rody w Austro-Węgrzech, które odmawiają narodom monarchii tego samego prawa, jakie uzgodniono dla narodów w Rosji (pokój brzeski). Szybki pokój zagwarantuje przyznanie wolności narodom Austro-Węgier. „Kto wyrywa kawałki z ciała państwa węgierskiego? Nie jest to naród czeski albo jego posłowie, ale sam morderczy układ szlachty węgierskiej, która uważa wszystkie narody niewęgierskie za helotów i czyni ich życie piekłem. Jest to kultura wszechludzka, która dziś bije też w baszty oligarchii węgierskiej, otwiera bramy węgierskich kazamatów i wzywa niewęgierskie narody, aby pokazały się ludzkości"' ${ }^{2}$. Następnie pisarz Alois Jirásek wygłosił uroczystą przysięgę, przyjętą przez zgromadzenie narodowe: „Wierni w pracy, wierni w walce, wierni w cierpieniu, wierni aż po grób! Wytrwamy, póki nie zwyciężymy! Wytrwamy, aż przywitamy niezależność naszego narodu! Bądź zdrów narodzie czechosłowacki!’’’3.

\footnotetext{
${ }^{10}$ Dokumenty slovenskej národnej identity a štátnosti II., red. M. Pekník, Bratislava 1998, s. 479-480.

11 Ibidem, s. 480.

12 „Lidové noviny”, 14 IV 1918, nr 101, s. 1.

13 Ibidem, s. 2.
} 
Publiczne uznanie organu zwierzchniego ruchu oporu za granicą, czyli Czechosłowackiej Rady Narodowej, przez rząd Francji 29 czerwca 1918 r. jako najwyższego organu narodu reprezentującego wszystkie jego interesy i jednocześnie uznanie Rady za fundament przyszłego rządu zbliżyło ruch niepodległościowy do celu, jakim było stworzenia państwa czecho-słowackiego. W warunkach krajowych istotne były natomiast zmiany organizacyjne w Komitecie Narodowym w Pradze, który na wniosek A. Švehli, został przekształcony w Czechosłowacki Komitet Narodowy (Národný výbor československý, dalej: NVČS). Doszło do tego 13 lipca 1918 r. podczas spotkania w Domu Miejskim w Pradze. Skład NVČS określono na podstawie wyników wyborów do Rady Państwa z 1911 r. Przewodniczącym został K. Kramár, wiceprzewodniczącymi: A. Švehla i V. Klofáč, a sekretarzem F. Soukup. Uczestnicy zgromadzenia wysłuchali i przyjęli wystąpienie Soukupa, które opublikowano w części prasy czeskiej jako oświadczenie NVČS. Głównym zadaniem Komitetu było skoncentrowanie wszystkich sił na osiągnięciu celu: ,prawo samostanowienia w niezależnym czeskim państwie czechosłowackim, z własną administracją we własnym domu"14. Jak widać, dla NVČS państwo czeskie i państwo czechosłowackie to były synonimy. Zaapelowano do opinii publicznej o respektowanie NVČS oraz o zachowanie spokoju i porządku. NVČS liczył 39 członków (w skład wchodziło 10 socjaldemokratów, 9 agrariuszy, 9 przedstawicieli Czeskiej Demokracji Państwowoprawnej, 4 narodowych socjalistów, 4 katolików, 1 staroczech, 1 realista, 1 reprezentant mniejszości czeskiej w Wiedniu) ${ }^{15}$. NVČS rozpoczął pracę 30 lipca 1918 r., a na posiedzeniu plenarnym zebrał się po raz pierwszy dopiero 29 września $1918 \mathrm{r}$.

Dziennikarz František Sís prowadził w imieniu Czechów rozmowy ze słowacką grupą w Wiedniu, aby zaproponowała ona przedstawicieli Słowaków do NVČS. Natomiast na Słowacji sondował nastroje i pertraktował w sprawie członkostwie w NVČS J. Rotnágl. W związku z niebezpieczeństwem ewentualnych represji wobec słowackich członków Komitetu ze strony władz węgierskich ostatecznie do jego składu nie wszedł żaden reprezentant ze Słowacji oprócz A. Štefánka, który zostal zastępcą członka NVČS. Słowaków reprezentował zatem od sierpnia 1918 r. tzw. komitet słowacki, składający się z Czechów, którzy mieli pewne związki ze Słowacją: F. Modráček — zastępca J. Záruba-Pfefferman, R. Pilát, A. Kolísek, J. Rotnágl — zastępca A. Štefánek ${ }^{16}$. NVČS utrzymywał regularne poufne kontakty z czecho-słowackim ruchem oporu za granicą, zaczął też zakładać powiatowe i gminne komitety narodowe. Odbywało się to za pośrednictwem „Mafii” oraz partii Czeska Demokracja Państwowoprawna (Česká štátoprávní demokracie). Przede wszystkim w Pradze udało się pozyskać dowództwo armii, policję państwową oraz zaufanych ludzi, którzy pilnowali rozmów telefonicznych. Opracowano listy osób, które tuż po rewolucji miałyby zająć stanowiska w administracji państwowej. W ten sposób stopniowo przygotowywano warunki do przejęcia władzy. Stosunki

14 „Lidové noviny”, 14 VII 1918, nr 190, s. 1.

15 V. Peša, Vznik Československé republiky 1918 a české národni výbory, Praha 1988, s. 13.

16 J. Rotnágl, Češi a Slováci. Vzpomínky a úvahy nad dopisy a zápisniky z let 1907-1918, Praha 1945, s. 226. 
w NVČS były jednak napięte. Niecierpliwi socjaliści 6 września 1918 r. stworzyli własną organizację - Radę Socjalistyczną i niezależnie od NVČS zaczęli przygotowywać akcje. Byli przekonani, że państwo czecho-słowackie istnieje już za granicą i należy je jak najszybciej proklamować w kraju. Ta próba przejęcia inicjatywy przyniosła 14 października 1918 r. ogłoszenie strajku protestacyjnego przeciwko wywożeniu artykułów spożywczych z terytorium „naszej Republiki Czechosłowackiej”. Zgodnie z instrukcją Rady Socjalistycznej w kilku czeskich miastach (Pilzno, Písek, Stará Boleslav, Třebíč, Morawska Ostrawa) doszło do ogłoszenia państwa czecho-słowackiego jako republiki socjalistycznej. Komitet Narodowy nie dołączył do tej akcji, ale ją potępił i nie dopuścił do jej eskalacji w Pradze. Rada Socjalistyczna ostatecznie podporządkowała się NVČC ${ }^{17}$.

Po uznaniu przez Francję 29 czerwca 1918 r. w Paryżu Czechosłowackiej Rady Narodowej jako przyszłego rządu inne mocarstwa złożyły podobne deklaracje. Rząd brytyjski ogłosił 9 sierpnia 1918 r. stanowisko w sprawie uznania Czechosłowackiej Rady Narodowej za przedstawiciela interesów narodowych i kuratora przyszłego rządu czecho-słowackiego. Następne były władze USA, które uznały Czechosłowacką Radę Narodową jako de facto rząd czecho-słowacki. Japonia uznała najwyższy organ czecho-słowackiego ruchu oporu za granicą 9 września 1918 r., a Włochy 3 października 1918 r. Proporcjonalnie do wzrostu znaczenia czecho-słowackiego ruchu niepodległościowego za granicą latem i jesienią 1918 r. malało znaczenie Austro-Węgier. Porażki militarne, bunty w armii, strajki oraz całkowite wyczerpanie gospodarcze były jasnym sygnałem agonii cesarstwa. Propozycja Austro-Węgier, aby w jednym z państw neutralnych zorganizować wielką konferencję pokojową, została odrzucona przez mocarstwa ententy. W atmosferze oczekiwania na rewolucyjne zmiany 2 października $1918 \mathrm{r}$. zebrał się parlament w Wiedniu. Wówczas czeski poseł F. Staněk wygłosił emocjonalne przemówienie, w którym krytykował politykę rządu: „Wybiła godzina, w której także w ramach imperium może zwyciężyć wszystko, co nie jest niemieckie lub węgierskie [...]. Nasi rodacy zorganizowali we wszystkich armiach ententy legiony czecho-słowackie. Tam nasi ludzie przelewali swoją krew za najbardziej idealne prawa ludzkości, tam pomagali w decydujących bitwach [...]. Naszym minimalnym programem jest państwo czechosłowackie, które będzie obejmować także węgierską Słowację w jej granicach geograficznych"18. Po tym przemówieniu Stanka doszło w parlamencie do bójki.

\section{AKTYWIZACJA CZECHO-SLOWACKIEGO RUCHU OPORU W KRAJU I ZA GRANICĄ W PAŹDZIERNIKU 1918 R.}

Dnia 4 października 1918 r. przywódcy Niemiec, Austro-Węgier i Turcji wysłali do prezydenta USA Wilsona prośbę o zawarcie natychmiastowego rozejmu. Jednocześnie wyrazili oni chęć negocjowania warunków pokoju na podstawie 14 punktów Wilsona ze stycznia 1918 r. Cesarz Austrii i król Węgier Karol próbował ratować monarchię poprzez jej federalizację, niemniej jego manifest z 16 października $1918 \mathrm{r}$. dotyczył tylko

17 J. Galandauer, Vznik Československé republiky..., s. 224-226.

${ }^{18}$ Stenographisches Protokoll. Haus der Abgeordneten, 85 Sitzung der XXII. Session am 2. Oktober 1918, s. 4316, 4319. 
austriackiej części monarchii. Węgierscy politycy nie chcieli federalizowania Węgier. Przedstawiciele narodu czeskiego, których manifest żywo dotyczył, zajęli wobec niego negatywne stanowisko w odrębnym oświadczeniu NVČS. Postrzegali manifest jako próbę zerwania jedności narodowej i terytorialnej. Na podstawie manifestu Karola 21 października 1918 r. w Wiedniu spotkali się niemiecko-austriaccy posłowie Rady Państwa jako Zgromadzenie Narodowe Posłów Niemieckich. Wzięło w nim udział 208 z 516 posłów. Ogłosili oni powstanie Republiki Niemieckiej Austrii (Deutschösterreich), do której miały należeć regiony z ludnością niemieckojęzyczną także w Czechach i na Morawach. Pierwszy rząd Niemieckiej Austrii powstał 30 października $1918 \mathrm{r}$.

Jeśli cesarz Karol w oczekiwaniu na notę prezydenta Wilsona wydał swój manifest, to Czechosłowacka Rada Narodowa w Paryżu zareagowała stworzeniem tymczasowego rządu czecho-słowackiego i wydaniem deklaracji waszyngtońskiej. Celem tych działań było niedopuszczenie do ewentualnego wahania mocarstw ententy w sprawie zachowania Austro-Węgier. Sekretarz Czechosłowackiej Rady Narodowej Edvard Beneš, za wiedzą Tomáša Masaryka, wysłał do przedstawicieli mocarstw ententy notę, w której poinformował o stworzeniu Czechosłowackiego Rządu Tymczasowego w składzie: T.G. Masaryk (prezydent rządu tymczasowego, prezes Rady Ministrów, minister finansów), E. Beneš (minister spraw zagranicznych) i M.R. Štefánik (minister wojny). Jednocześnie Beneš wyznaczył pierwszych dyplomatów czechosłowackich. W wyniku powstania tego rządu 14 października 1918 r. przestała istnieć Czechosłowacka Rada Narodowa. Rząd stopniowo uznawały inne państwa: Francja (15 października), Wielka Brytania i Serbia (23 października), Włochy (24 października), USA (12 listopada). Masaryk w czasie wydania noty Beneša w sprawie Rządu Tymczasowego przebywał w Stanach Zjednoczonych i w związku z przygotowaniami USA do odpowiedzi na austro-węgierski wniosek o rozejm i próbę zachowania w jakiejś formie Austro-Węgier postanowił wydać deklarację niepodległości narodu czecho-słowackiego (Vyhlásenie nezávislosti Československého národa), tzw. deklarację waszyngtońską. Jej tekst przekazał 17 października 1918 r. rządowi USA. Doszło do tego zanim w ręce władz USA trafił tekst manifestu Karola i oba dokumenty zostały opublikowane w prasie tego samego dnia, przeważnie obok siebie. W deklaracji waszyngtońskiej Beneš odrzucił federalizację monarchii i jednocześnie wyraził nadzieję, że wolne narody Europy Środkowo-Wschodniej z łatwością stworzą federację, jeśli uznają to za potrzebne. Odwołał się do idei nowoczesnej demokracji i naszkicował najważniejsze zasady konstytucji: państwo czecho-słowackie będzie republiką, w której zostaną zagwarantowane wszystkie wolności obywatelskie oraz zostanie wprowadzone powszechne prawo wyborcze, Kościół zostanie oddzielony od państwa, kobiety będą miały zapewnioną zupełną równość z mężczyznami pod względem politycznym, socjalnym i kulturalnym, mniejszości będą chronione, stałą armię zastąpi milicja, zostaną też przeprowadzone daleko idące reformy gospodarcze i społeczne ${ }^{19}$.

19 J. Galandauer, Vznik Československé republiky..., s. 311-314. 
Węgierski parlament zebrał się na historycznym ostatnim posiedzeniu 16 października 1918 r. Inicjatorem jego zwołania był opozycyjny polityk, socjaldemokrata Mihály Károlyi. Już pierwszy dzień obrad był burzliwy. Premier węgierskiego rządu Sándor Wekerle apelował o jedność w interesie zachowania integralności Węgier. Temu celowi miały służyć też rozmowy z przedstawicielami narodów niewęgierskich. Pewne otrzeźwienie stanowiło wystąpienie Károlyi’ego, który oświadczył: „Przegraliśmy wojnę, teraz nie możemy przegrać też pokoju". Domagał się on szybkiego przeorientowania węgierskiej polityki na kurs demokratyczny. W tych pełnych napięcia dniach katolicki ksiądz Ferdinand Juriga znalazł odwagę, aby wystąpić w parlamencie węgierskim jako jedyny aktywny słowacki poseł. Przygotował swoje wystąpienie według wzoru oświadczenia posłów rumuńskich, którzy opowiedzieli się za prawem do samostanowienia i nie uznali prawa parlamentu i rządu węgierskiego do decydowania o Rumunach. Juriga wystąpił w parlamencie 19 października 1918 r. Posłowie węgierscy ograniczyli się do ataków słownych. Juriga mówił w imieniu i z upoważnienia Słowackiej Rady Narodowej (Slovenská národná rada, dalej: SNR), która ledwo co zaczynała się tworzyć. ,Jesteśmy narodem z własnym zdaniem, mową i nie opuścimy samych siebie, domagamy się naszego prawa do samostanowienia, na podstawie naturalnego i historycznego prawa, jak chce tego też król Karol, żebyśmy jako jednostka narodowościowa stworzyli sobie swoją własną państwowość, na obszarze, na którym zamieszkaliśmy [...]. Do tego z odpowiedzialnością domaga się też dla siebie tego prawa, aby w zupełnej swobodzie i bez jakiegokolwiek cudzego wpływu mógł sam rozstrzygać o swojej konstytucyjnej sytuacji państwowej i stosunku do pozostałych wolnych narodów. Naród słowacki nie uznaje prawa tego parlamentu i jego rządu [...]. Naród słowacki nie przyznaje innemu, obcemu mu czynnikowi takiego prawa, aby na powszechnym kongresie pokojowym reprezentował on interesy narodu słowackiego, ponieważ reprezentowanie tych interesów może powierzyć tylko czynnikom wyznaczonym przez Słowacką Radę Narodową [...]. Domagamy się naszego prawa do samostanowienia na życie i na śmierć. Z tym żyjemy! Z tym umieramy"20. Znaczenie oświadczenia Jurigi polega na tym, że w imieniu Słowaków jasno zadeklarował on zasady demokracji, prawa do samostanowienia i federalizmu. Słowa te nie spotkały się z odzewem polityków czeskich, ponieważ Juriga nie wspomniał o chęci połączenia Słowaków z Czechami w jednym państwie. Ostatnim czeskim posłem, który 22 października 1918 r. wystąpił w austriackiej Radzie Państwa w Wiedniu, był František Udržal. Nie wygłosił on żadnego oświadczenia, tylko stwierdził po czesku, że właściwie nie ma już o czym mówić: „Po znanych wydarzeniach historycznych nie mamy wam nic do powiedzenia”. Następnie jednak wygłosił kilka zdań. Jeśli za wojnę odpowiada austro-węgierski imperializm, to należy dodać, że jej intelektualnym sprawcą był dualizm austro-węgierski, który uciskał narody i służył niemieckim interesom imperialnym. Na zakończenie dodał: „Każda nadzieja

${ }^{20}$ Országgyűlés képviselőházának naplója. XLI. kötét. 826. országos ülés 1918 október 19-én, szombaton. Budapest: Hiteles kiadás, 1918, s. 345. 
na uratowanie Austro-Węgier przypomina dziś psa myśliwskiego, który zgubił trop. Nie da się więcej uratować". ${ }^{21}$

Prezydent USA Wilson odpowiedział na austro-węgierską prośbę o rozejm notą swojego sekretarza stanu R. Lansinga z 18 października 1918 r. W nocie podkreślono, że prezydent nie może się zgodzić na propozycję rządu austro-węgierskiego w sprawie swoich 14 punktów ze stycznia 1918 r., ale obstaje przy tym, żeby zaspokoić aspiracje narodów Austro-Węgier. Nadszedł czas oczekiwania na odpowiedź na tę notę, przy czym powszechnie spodziewano się kapitulacji Austro-Węgier. Podczas całodniowego posiedzenia NVČS i Związku Czeskiego w Pradze 19 października 1918 r. przyjęto plany reorganizacji przedstawione przez A. Švehlę. NVČS zaczął działać w sposób permanentny. Jego prezydium i komisje zaczęły urzędować codziennie, a posiedzenia plenarne odbywały się raz na dwa tygodnie, z tym że wszyscy członkowie mieli być w gotowości, tak aby posiedzenie mogło zostać zwołane w każdej chwili. Liczba członków NVČS uległa potrojeniu z zachowaniem klucza partyjnego określonego na podstawie wyników wyborów w 1911 r. Podjęto decyzję o stworzeniu powiatowych komitetów narodowych ${ }^{22}$. W atmosferze oczekiwania przedstawiciele NVČS postanowili udać się do Genewy, aby za namową Beneša spotkać się z przedstawicielami czecho-słowackiego ruchu oporu za granicą i uzgodnić dalsze kroki. Ani rząd austriacki ani cesarz Karol nie stwarzali problemów. NVČS był reprezentowany przez jego przewodniczącego K. Kramářa i wiceprzewodniczącego V. Klofáča, a Związek Czeski przez jego przewodniczącego F. Stanka, wiceprzewodniczącego G. Habermana i posła A. Kalinę. Ponadto w skład delegacji weszli dwaj eksperci finansowi - dyrektorzy banków: J. Preiss i K. Svoboda. Z delegacją na rozmowy informacyjne do Wiednia podróżował także A. Rašín, który później wrócił do Pragi. Kramářa i Klofáča w NVČS zastępowali podczas ich nieobecności A. Rašín i J. Stříbrný. Delegaci podróżowali przez Wiedeń, gdzie 25 października 1918 r. rozmawiali z przedstawicielami Słoweńców, Słowaków i Polaków. Uzgodniono tam wspólne postępowanie — należy odrzucić wszystkie rokowania z Wiedniem i Budapesztem i „popędzać sprawy ku kapitulacji”. Delegacja czeska przekazała na Słowację zalecenia, aby zachowywać wstrzemięźliwość i nie podejmować jednoznacznego stanowiska w sprawie państwa czecho-słowackiego. To wywarło wpływ na stanowisko słowackie oraz brzmienie przyjętej później deklaracji narodu słowackiego.

Nikt nie podejrzewał, że do powstania Czechosłowacji dojdzie właśnie wtedy, kiedy czołowi przedstawiciele ruchu będą za granicą. Rozmowy prowadzono w genewskim hotelu. Oprócz Beneša zagraniczny ruch oporu reprezentowali też dwaj Słowacy: Š. Osuský i Ivan Markovič. Rozmawiano o potrzebie szybkiego opanowania militarnego całego państwa, technice oraz odpowiednim momencie do przejęcia władzy. Uzgodniono skład przyszłego rządu — premierem miał zostać K. Kramár, a prezydentem T.G. Masaryk. Delegacja powróciła ze Szwajcarii dopiero 5 listopada

21 Stenographisches Protokoll. Haus der Abgeordneten, 92 Sitzung der XXII. Session am 22. Oktober 1918 , s. $4667,4669$.

${ }^{22}$ A. Klimek, Řijen 1918. Vznik Československa, Praha 1998, s. 120. 
1918 r., czyli tydzień po proklamowaniu państwa czecho-słowackiego. Tym samym nie udało się zrealizować powstania Czechosłowacji według z góry przygotowanego scenariusza, jak to sobie wyobrażali Masaryk i Beneš, przedstawiciele ruchu niepodległościowego za granicą.

\section{PROKLAMACJA PAŃSTWA CZECHO-SLOWACKIEGO} 28 PAŹDZIERNIKA 1918 R. W PRADZE ORAZ PRZYJĘCIE DEKLARACJI NARODU SLOWACKIEGO W MIEŚCIE TURČIANSKY SV. MARTIN 30 PAŹDZIERNIKA 1918 R.

Sytuacja 27 października 1918 r. była napięta, a atmosfera pełna oczekiwania. Nerwowe komunikaty austriackiego sztabu generalnego o tym, aby NVČS uspokoił czeskich żołnierzy na froncie, stanowiły dla Rašína sygnał do wydania wytycznych w sprawie środków bezpieczeństwa ${ }^{23}$. W nocy z 27 na 28 października 1918 r. opracował on projekt ustawy o powstaniu państwa czecho-słowackiego, na podstawie elaboratu czeskiego prawnika Ferdinanda Pantǔčka, radcy dworu Najwyższego Sądu Administracyjnego w Wiedniu. To opracowanie było rezultatem prac komisji NVČS, która zajmowała się podstawami konstytucyjnymi przyszłego państwa ${ }^{24}$. W ciągu najbliższych godzin spodziewano się rewolucji. Wczesnym rankiem 28 października 1918 r. A. Rašín i F. Soukup przejęli — w imieniu NVČS — istotny ze strategicznego punktu widzenia Wojskowy Instytut Zbożowy. W tym czasie na praskich ulicach panowało już ożywienie. W nadzwyczajnych wydaniach gazet publikowano treść noty austro-węgierskiej z 27 października 1918 r., która stanowiła odpowiedź na notę amerykańską. Stwierdzono w niej, że rząd Austro-Węgier zgadza się z opinią prezydenta Wilsona zawartą w ostatniej nocie o prawach narodów austro-węgierskich, ,zwłaszcza o prawach Czechosłowaków i Jugosłowian”. Opinia publiczna uznała tę wiadomość za kapitulację Austro-Węgier, choć władca i rząd jeszcze urzędowali, a armia walczyła. Delegacja NVČS w Pradze natychmiast wybrała się do urzędu namiestnika w Pradze, gdzie A. Švehla oświadczył zastępcy nieobecnego namiestnika J. Kosinowi, że NVČS przejmuje administrację publiczną kraju jako części państwa czecho-słowackiego, przy czym wszystkie ustawy tymczasem pozostają w mocy. Następnie delegacja odwiedziła prezydenta Krajowej Komisji Administracyjnej hrabiego V. Schönborna. Oświadczyła mu, że NVČS tego dnia przejmuje gmach parlamentu krajowego z salą obrad (Pałac Thunów na ulicy Sněmovní na Malej Stranie). Było to istotne, ponieważ kierownictwo NVČS liczyło się już z wykorzystaniem tego budynku na pierwsze posiedzenie rewolucyjnego Zgromadzenia Narodowego. Sytuacja na sali była niewesoła: „Na ziemi walały się ziemniaki i kasza, na miejscach dla posłów stały worki z mąką, powietrze było przesycone wonią ziemniaków i zapachem produktów mącznych. Na stole prezydialnym leżał worek z kaszą. Poleciliśmy, aby natychmiast zrobiono porządek na sali posiedzeń, co obecni słudzy obiecali z radością"25. NVČR dzięki racjonalnemu podejściu do sytuacji

${ }^{23}$ Paměti Dr. Aloise Rašina, red. A. Rašín, Brno 1994, s. 213.

${ }^{24}$ F. Soukup, 28. ř́jen 1918, t. 2, Praha 1928, s. 1005.

${ }_{25}$ Paměti Dr. Aloise Rašina..., s. 214. 
w pierwszych godzinach przewrotu zapewnił sobie istotną neutralność najważniejszych urzędów, które w pełni oddały się do dyspozycji nowego państwa.

W tym czasie ludzie zaczęli się zbierać i niszczyć symbole państwowe Austro-Węgier. Prezydium NVČS: A. Švehla, A. Rašín, F. Soukup i J. Stř́ibrný kazali się przewieźć w otwartym aucie na plac Wacława. Tam mówili o nowym państwie, otoczeni przez rozradowany tłum. Po godz. 17 w Domu Miejskim w Pradze zebrało się plenum NVČS. Švehla zaproponował, aby NVČS przejął rządy w wyzwolonej ojczyźnie i ogłosił jej suwerenność. Następnie odczytał projekt ustawy, na podstawie której miało to nastąpić. W jej preambule zapisano, że niezależne państwo czechosłowackie rozpoczęło swoje istnienie, a NVČS jako wykonawca suwerenności państwowej zarządził w imieniu narodu czechosłowackiego, co następuje: 1) formę ustrojową państwa miało określić Zgromadzenie Narodowe w porozumieniu z Czechosłowacką Radą Narodową w Paryżu. Do tego czasu organem wykonawczym suwerenności państwowej miał być NVČS; 2) wszelkie dotychczasowe ustawy, rozporządzenia państwowe i krajowe miały nadal pozostać w mocy; 3) wszystkie urzędy samorządowe, państwowe i okręgowe, instytucje państwowe, krajowe, powiatowe i gminne miały zostać podporządkowane NVČS i działać zgodnie z obowiązującym prawem; 4) ustawa miała wejść w życie z dniem 28 października 1918 r.; 5) za wykonanie ustawy miało odpowiadać Prezydium NVČS. Następnie otwarto dyskusję. Na uwagę socjaldemokraty F. Modráčka, że za granicą funkcjonuje już rząd Masaryka i nie ma potrzeby, aby NVČS też stał się rządem, odpowiedziano, że nie ma możliwości szybkiego i stałego kontaktu z gabinetem za granicą, dlatego z powodów pragmatycznych postanowiono rozszerzyć kompetencje NVČS. Pierwszą ustawę nowego państwa podpisali: A. Švehla, J. Stř́ibrný, A. Rašín, F. Soukup i za Słowaków V. Šrobár ${ }^{26}$. Słowak Šrobár, wcześniej więziony, pojawił się w Pradze dopiero 28 października 1918 r. rano. Przywiodła go intuicja, że właśnie tu zapadną najważniejsze decyzje. Prawdopodobnie, gdyby Šrobár nie przyjechał, to ustawę o powstaniu państwa czecho-słowackiego podpisałby inny przedstawiciel Słowaków przebywający w Pradze. Pojawienie się Šrobára pozwoliło jednak w pełni wykorzystać symboliczny gest obecności Słowaka podczas proklamowania czecho-słowackiego państwa. Demonstracje uliczne w Pradze wywołały reakcję wojska, które po południu zajęło plac Wacława oraz rynek Starego Miasta. Przedstawiciele NVČS prowadzili skomplikowane, lecz zakończone sukcesem negocjacje w sprawie wycofania wojsk. Sytuacji nie zmieniła już nawet próba ogłoszenia przez kilku nadgorliwych oficerów stanu wyjątkowego w nocy z 29 na 30 października 1918 r.

Zwołanie komitetu SNS do Martina, na które oficjalnie wyraziły zgodę władze węgierskie, stało się najważniejszym wydarzeniem politycznym na Słowacji. Osobistości słowackie zaczęły zjeżdżać do Martina już 29 października 1918 r., aby omówić dalsze postępowanie. W pogotowiu były też organy rządowe. Na wszelki wypadek została skierowana do Martina rota 15 pułku honwedów. Był to ważny moment psychologiczny, który miał przypominać obecnym o węgierskich władzach państwowych.

${ }^{26}$ A. Klimek, Říjen 1918. Vznik Československa..., s. 214-216. 
30 października 1918 r. przed południem rozpoczęło się posiedzenie komitetu wykonawczego SNS w gmachu martinskiej Tatrabanky. Projekt księdza ewangelickiego Samuela Zocha, który zawierał też uwagi Jurigi, został przyjęty przez obecnych bez poważniejszych zmian i stał się podstawą tekstu deklaracji narodu słowackiego. Na przebieg przedpołudniowego posiedzenia wywarła znaczny wpływ obecność I. Dérera, który właśnie przyjechał do Martina z Wiednia, gdzie spotkał się z członkami delegacji NVČS, udającymi się do Genewy. Dérer przekazał opinię Kramářa, według którego nie należało spieszyć się z ogłoszeniem jednoznacznych stanowisk w sprawie państwa czecho-słowackiego, ponieważ najpierw należało się dowiedzieć, czy połączenie Słowaków i Czechów w jednym państwie zostanie zagwarantowane przez mocarstwa ententy. Dérer nie zalecał podkreślania odrębności Słowaków, tak jak nie zalecał „samorządu wobec Czech: ten zostanie podobno urządzony jak w domu"27. Narady w Martinie kontynuowano po południu podczas zgromadzenia w sprawie przyjęcia deklaracji, któremu przewodniczył M. Dula. Według zachowanych protokołów wzięło w nim udział 106 osób. W rzeczywistości było ich więcej, ponieważ część się nie podpisała. Ciekawostką jest, że nie zezwolono na udział w zgromadzeniu reprezentantek słowackich kobiet, choć domagały się tego za pośrednictwem L’udmily Podjavorinskej. Zgromadzenie wybrało 20 członków SNR, a spośród nich 12-osobowy komitet wykonawczy (Matúš Dula, Metod M. Bella, Vladimír Makovický, Andrej Hlinka, Vavro Šrobár, Ján Ružiak, F. Juriga, Kornel Stodola, Emanuel Lehocký, S. Zoch, Emil Stodola i Ludovít Bazovský), przy czym wzięto pod uwagę to, żeby jego członkowie mogli pracować w różnych miastach Słowacji i całej monarchii. Liczba członków SNR mogła zostać uzupełniona do 100 osób. S. Zoch przeczytał zgromadzonym deklarację narodu słowackiego. Obecni słuchali z uwagą, a następnie zabierali głos poszczególni mówcy. Wieczorem 30 października 1918 r. przybył do Martina M. Hodža. Kiedy przedstawiono $\mathrm{mu}$ tekst dokumentu, dokonał w nim jednej zmiany. Wyrzucił zdanie o samodzielnej reprezentacji Słowacji na konferencji pokojowej, a w jego miejsce wstawił sformułowanie, że Słowacy akceptują położenie prawnomiędzynarodowe wynikające z noty Wilsona i odpowiedzi Austro-Węgier na nią. Ingerencję Hodžy wprawdzie zatwierdziła tzw. komisja redakcyjna ds. deklaracji, lecz była to zmiana, która stanowiła niepotrzebny impuls do późniejszych komentarzy o fałszowaniu tego dokumentu, wygłaszanych w 1923 r. przez L. Bazovskiego i A. Hlinkę. Nikt nie mógł zagwarantować, że doszło tylko do tej jednej zmiany. Nie można było tego zweryfikować, ponieważ oryginał deklaracji zaginął. 30 października 1918 r. okazał się pod pewnym względem szczęśliwym terminem na zorganizowanie zgromadzenia i przyjęcie deklaracji. Właśnie tego dnia masowe demonstracje w Budapeszcie przerodziły się w rewolucję. Możliwości działania aparatu państwa zostały sparaliżowane i nikt nie podjął interwencji przeciwko uczestnikom zgromadzenia w Martinie.

Znaczenie deklaracji narodu słowackiego polega na tym, że doszło do zjednoczenia wszystkich sił politycznych w SNR. Suwerenna SNR publicznie ogłosiła się

${ }^{27}$ M. Hronský, M. Pekník, Martinská deklarácia. Cesta slovenskej politiky k vzniku Česko-Slovenska, Bratislava 2008, s. 268. 
jedynym organem upoważnionym do tego, aby wypowiadać się i działać w imieniu narodu słowackiego, jednocześnie zakwestionowała ona kompetencje rządu i parlamentu węgierskiego. Uczestnicy zgromadzenia w Martinie nie mieli świadomości, że w Pradze proklamowano już powstanie czecho-słowackiego państwa. W deklaracji nie wspomina się bezpośrednio o państwie czecho-słowackim, ale prawo do jego utworzenia zostało wyrażone w zasadzie samostanowienia narodu czecho-słowackiego na Węgrzech. Publicznie zatem otwarto Słowacji furtkę do tego rozwiązania. W deklaracji obok pojęcia „naród czechosłowacki” pojawił się też termin „,naród słowacki”, co świadczy o celowym posłużeniu się pojęciem ,naród czechosłowacki”. Przewodniczący SNR M. Dula wysłał po zakończeniu zgromadzenia telegram do NVČS, w którym jednoznacznie opowiedział się za bezwarunkowym prawem do samostanowienia narodu słowackiego i jego udziałem w stworzeniu państwa czecho-słowackiego ${ }^{28}$. Było to potwierdzeniem podstawowego stanowiska słowackiej reprezentacji politycznej z maja 1918 r. Tekst deklaracji został w Pradze przekazany NVČS przez delegację SNR w składzie: I. Dérer, Fedor Houdek i Jozef Hanzalík. Przybyli oni do Pragi wieczorem 1 listopada 1918 r. Do powstania państwa czecho-słowackiego doszłoby zapewne także bez deklaracji narodu słowackiego, ale byłaby to raczej forma realizacji idei przyłączenia Słowacji do państwa czeskiego, bez wyrażenia własnej woli przez przedstawicieli narodu słowackiego. Takie rozwiązanie, w którym Słowacja staje się tylko obiektem zainteresowania silniejszych sąsiednich narodów, było nie do przyjęcia w kontekście teraźniejszości i przyszłości Słowaków. Na dodatek legitymizowałoby ono węgierskie roszczenia wobec Słowacji. Podstawę węgierskiej argumentacji mogłaby w o wiele większym zakresie stanowić teza o aneksji części terytorium Węgier przez Czechy.

Uczestnicy zgromadzenia rozjechali się po jego zakończeniu. W Martinie pozostali członkowie SNR i jej komitetu wykonawczego, którzy 31 października 1918 r. rozmawiali o kwestiach prawnych powstającego państwa. Impulsem do rozmów był projekt czeskiego prawnika F. Panti̊čka, który zakładał przeniesienie czeskiego systemu administracji publicznej i finansowej, szkolnictwa i sądownictwa na Słowację. Regionalna (żupna) administracja publiczna, istniejąca na Słowacji, miała zostać zlikwidowana i zastąpiona przez jednolitą administrację polityczną na wzór Czech. Zakładano ustanowienie samorządu na wzór czeski na poziomie gmin, żup i krajów. Słowaccy uczestnicy narady byli zaskoczeni projektem Pantůčka, ponieważ nie znali wystarczająco dobrze reguł funkcjonowania administracji w Czechach. W zasadzie z nim się jednak zgadzali, ale według nich na początku lepiej byłoby rządzić w sposób autokratyczny i dopiero później, kiedy sytuacja stanie się bardziej klarowna, wprowadzić taki typ administracji, jaki będzie odpowiadać Słowacji i całemu państwu. Uzgodniono, że „po wprowadzeniu okresu przejściowego, najpóźniej jednak do 10 lat, zostanie uregulowana sytuacja prawnopaństwowa dotychczas żyjącego na Węgrzech szczepu naszego narodu w formie umowy między legalnymi przedstawicielami Słowacji z jednej strony a Czech, Moraw

${ }^{28}$ M. Hronský, Slovensko pri zrode Československa, Bratislava 1987, s. 304. 
i Śląska z drugiej strony”29. Tak to miano podać do publicznej wiadomości. Wprawdzie inspiracja tego sformułowania był projekt Pantůčka, ale nie dotyczyło to już tylko tego dokumentu, ale szerszej kwestii autonomii samorządu Słowacji w państwie czecho-słowackim. Miało dojść do umowy między przedstawicielami Czech i Słowacji. Słowacji nie traktowano jak partnera na poziomie Moraw lub Śląska, ale jako jednostkę terytorialną równorzędną wobec wszystkich trzech ziem czeskich łącznie. W dyskusji wykrystalizowały się dwa poglądy: za autonomią Słowacji w ramach państwa czecho-słowackiego i przeciwko niej. Problem samorządu Słowacji był rzeczywiście delikatny i — jak się okazało — stanowił źródło polaryzacji poglądów. Może także dlatego nie przyjęto jednoznacznej uchwały w tej sprawie, lecz tylko wnioski z narady. Cały problem odłożono na przyszłość, do zakończenia okresu przejściowego. W każdym razie błędem było to, że słowacka reprezentacja polityczna nie umiała zająć wspólnego i wiążącego stanowiska w kwestii pozycji Słowacji w przyszłym państwie czecho-słowackim. Powszechne zapewnienia niektórych miarodajnych polityków czeskich o tym, że Słowacja dostanie to, czego będzie się domagać, czy też odkładanie problemu na przyszłość bez zajęcia stanowiska przez stronę słowacką prowadziło do diametralnie odmiennych interpretacji, które miały bardzo negatywny wpływ na rozwiązanie kwestii słowackiej. Politycy słowaccy w czasie powstawania państwa myśleli bardziej o tym, jak opuścić Węgry przy jak najmniejszych stratach niż o warunkach i gwarancjach, na jakich Słowacja stanie się częścią nowego państwa. Na Słowacji suwerennym przedstawicielem narodu słowackiego była SNR w Martinie. Nie miała ona jednak dość sił na to, aby przekształcić się w bardziej trwałą instytucję. Do jej słabości przyczyniła się ciągła obecność węgierskich organów władzy oraz absolutny brak słowackiej inteligencji uświadomionej narodowo. Podobnie jak SNR tworzyła na obszarze Słowacji lokalne rady i gwardie narodowe, tak tworzyła je również budapesztańska Węgierska Rada Narodowa. Doszło też do osłabienia SNR od wewnątrz, ponieważ istotna grupa osób, na czele z V. Šrobárem, wolała zaangażować się w działalność w Pradze w ramach NVČS, który po 28 października 1918 r. pełnił funkcje rządu. Ta grupa nie była zainteresowana wsparciem SNR. W samym NVČS trudno było dostrzec chęć uznania SNR za instytucję, którą należy wspierać jako ośrodek władzy tworzącego się państwa czecho-słowackiego na Słowacji. W ten sposób już podczas powstawania państwa czecho-słowackiego tworzyły się zręby przyszłego centralizmu państwowego.

\section{REWOLUCYJNE ZGROMADZENIE NARODOWE I TYMCZASOWA KONSTYTUCJA}

Kiedy 30 października 1918 r. zakończyły funkcjonowanie organy starych władz państwowych, NVČS w Pradze stał się centralnym organem władzy całego państwa czecho-słowackiego. Plenum NVČS obradowało nieprzerwanie od 28 do 31 października 1918 r., a następnie dwa razy w tygodniu: 2, 5, 9 i 13 listopada 1918 r. NVČS skupiał całą władzę ustawodawczą i wykonawczą. Od 28 października do 14 listopada

29 „Naše revoluce” 1932, nr 8, s. 178. 
wydał 17 ustaw i 23 rozporządzenia. Te przepisy prawa wymuszała aktualna sytuacja, na ich mocy tworzono najważniejsze instytucje państwowe, chroniono majątek państwa i obywateli, zapewniano zaopatrzenie. Zakres działania NVČS był w tym czasie bardzo szeroki. NVČS skupiał się na konsolidacji sytuacji w nowym państwie, przede wszystkim przejmowaniu urzędów, kwestiach zaopatrzenia i wojska. Każdego dnia przychodziło do niego średnio tysiąc pism i około 400 interesantów z różnymi wnioskami i interwencjami. Pomieszczenia NVČS były niewystarczające. Jego biuro, które liczyło ponad 100 pracowników, 31 października 1918 r. przeniesiono z Domu Miejskiego do Pałacu Harrachów na ulicy Jindřišskiej, a stamtąd do szkoły kadetów na Hradczanach ${ }^{30}$. 30 października na posiedzeniu plenarnym postanowiono podwoić liczbę członków NVČS do 256, ponownie według klucza wyborczego określonego na podstawie wyników wyborów parlamentarnych z $1911 \mathrm{r}$. Był to konkretny krok na drodze do stworzenia rewolucyjnego tymczasowego Zgromadzenia Narodowego. 2 listopada $1918 \mathrm{r}$. na posiedzeniu plenarnym NVČS zgłoszono wniosek w sprawie utworzenia odrębnych resortów ministerialnych (kierowanych przez specjalistów), które uznano za bardziej praktyczne niż praca w komisjach i wydziałach. Na podstawie ustawy nr 2/1918 ustanowiono najwyższe urzędy administracyjne w państwie czecho-słowackim. „Skompromitowanego" terminu ministerstwo tymczasowo nie używano. W sumie utworzono 12 resortów, ale później ich liczba wzrosła do 13. Od 5 listopada 1918 r. NVČS zajmował się przygotowaniami do zwołania rewolucyjnego ustawodawczego Zgromadzenia Narodowego. Pewne opóźnienie można wytłumaczyć oczekiwaniem na powrót delegacji, pod kierownictwem K. Kramářa z Genewy, która miała przywieźć zasadnicze informacje w kwestii zorganizowania państwa. NVČS przyjął 9 listopada 1918 r. ustawę nr 36/1918 w sprawie porządku obrad Zgromadzenia Narodowego, a następnie 13 listopada 1918 r. ustawę nr 37/1918 w sprawie tymczasowej konstytucji.

Nad konstytucją pracowano jeszcze przed rewolucją. Było to przede wszystkim dzieło referenta komisji konstytucyjnej NVČS Alfréda Meissnera. W § 1-6 tymczasowej konstytucji zdefiniowano kompetencje Zgromadzenia Narodowego. W § 1 określono, że Komitet Narodowy zostanie powiększony do 256 członków i że to gremium będzie nosiło nazwę Zgromadzenia Narodowego. W § 4 określono, że Zgromadzenie Narodowe ma posiadać kompetencje ustawodawcze na terenie całego kraju i jego części oraz kompetencje nadzorcze wobec władzy wykonawczej aż do czasu, kiedy po regularnych wyborach parlamentarnych zostanie ustanowiony parlament. Zgodnie z $§ 6$ Zgromadzenie Narodowe mogło obradować i podejmować decyzje w obecności co najmniej 1/3 liczby posłów. Decyzje podejmowano zwykłą większością głosów. Obecność $2 / 3$ liczby posłów oraz większość $2 / 3$ głosów była wymagana do zmiany tymczasowej konstytucji, porządku obrad, wyboru prezydenta państwa oraz wypowiedzenia wojny ${ }^{31}$. Ponadto określono kompetencje prezydenta i rządu, przy czym zwiększono liczbę ministerstw do 17 (§14).

${ }^{30}$ V. Peša, Vznik Československé republiky 1918 a české národní výbory..., s. 31.

${ }^{31}$ Sbirka zákonů a nařizeni státu československého, t. VI, vydaná 14. listopadu 1918. Zákon č. 37 ze dne 13. listopadu 1918 o prozatímní ústavě, s. 30. 
Pierwsze posiedzenie rewolucyjnego Zgromadzenia Narodowego odbyło się 14 listopada $1918 \mathrm{r}$. w — jak to określono w porządku obrad — gmachu parlamentu królestwa czeskiego. Ten budynek był zbyt mały i od początku traktowano go jako siedzibę tymczasową. Pobliski plac był pełen ludzi już na kilka godzin wcześniej. Członkowie organizacji gimnastycznej Sokół i stowarzyszeń strzeleckich musieli rozdzielać publiczność, aby posłowie mogli przejść korytarzem do budynku, do którego można było się dostać tylko z zaproszeniami. Ludzie, którzy pozostali na zewnątrz, byli informowani o przebiegu obrad przez część posłów ${ }^{32}$. Posiedzenie rozpoczęło się o godz. 11.40 wystąpieniem K. Kramářa, który przypomniał o ofiarach, które doprowadziły do powstania państwa czecho-słowackiego oraz podziękował wszystkim mocarstwom i sojusznikom, którzy pomagali w walce o powstanie nowego państwa. Kwestia ustroju republikańskiego państwa nie była przedmiotem dyskusji. Kramár po prostu oświadczył — bez przeprowadzenia głosowania - że wszystkie więzi z dynastią habsbursko-lotaryńską zostają zerwane, przestają obowiązywać umowy z 1526 r. i sankcja pragmatyczna, że dynastia habsbursko-lotaryńska straciła wszystkie prawa do czeskiego tronu i „my swobodni i wolni ogłaszamy, że nasze państwo czecho-słowackie jest wolną Republiką Czechosłowacką. Wspaniale! Chwała! Głośne oklaski" ${ }^{33}$. Następnie krótko zaapelował, aby posłowie na pierwszego prezydenta wybrali T.G. Masaryka. Stało się to przez aklamację, przy burzliwych oklaskach i okrzykach chwały. Kramáŕ ogłosił, że Masaryk został jednogłośnie wybrany prezydentem Republiki Czechosłowackiej (Československá republika, dalej: ČSR). Po przemówieniu Kramářa wybrano przewodniczącego rewolucyjnego Zgromadzenia Narodowego. Został nim socjaldemokrata František Tomášek. Zapewnił, że ČSR będzie państwem demokratycznym, które przeprowadzi dalekosiężne reformy społeczne. Pozdrowił Słowaków, podkreślił moment czecho-słowackiej jedności narodowej i dodał, że przedstawiciele Niemców nie muszą się obawiać przyszłości. Następnie posłowie złożyli przysięgę i wybrano czterech wiceprzewodniczących Zgromadzenia Narodowego. Byli to: František Udržal (partia agrarna), Antonín Hajn (narodowa demokracja), Alois Konečný (partia socjalistyczna), Metod Bella (za Słowaków). Ewangelicki ksiądz Metod Bella zabrał głos, podziękował w imieniu Słowaków narodowi czeskiemu za pomoc i poprosił o dalsze wsparcie militarne potrzebne do wyzwolenia Słowacji. Zgromadzenie Narodowe przeszło następnie do wyboru przez aklamację prezesa Rady Ministrów i 16 jej członków. Pierwszym premierem został K. Kramář. Premier i członkowie rządu złożyli ślubowanie. W ten sposób oddzielono władzę wykonawczą od władzy ustawodawczej ${ }^{34}$.

Krótko po pierwszym posiedzeniu rewolucyjnego Zgromadzenia Narodowego pojawiły się wątpliwości, czy to ciało ustawodawcze i jego komisje nie wykraczają poza zwyczajowo przyjęte granice i zadania organu ustawodawczego. Jedni uważali, że rewolucyjne Zgromadzenie Narodowe jest w pełni legalnym i uprawnionym gremium

32 „Národní listy”, 15 XI 1918, nr 132, s. 1.

${ }^{33}$ Národní shromáždění československé, Stenografické protokoly, 1. schůze, 14.11.1918.; vide <https:// www.psp.cz>.

${ }^{34}$ Ibidem. 
prawodawczym, które ma nieograniczone kompetencje i ma prawo uczynić wszystko, co uważa za stosowne, w tym również przyjąć konstytucję. Natomiast inni twierdzili, że rewolucyjne Zgromadzenie Narodowe jest tymczasowym i niepochodzącym z wyborów ciałem ustawodawczym, dlatego jak najszybciej powinno zostać zastąpione przez regularnie wybrany parlament ${ }^{35}$. $Z$ tego powodu grupa posłów pod kierownictwem J. Šrámka 18 grudnia 1918 r. złożyła wniosek w sprawie zasadniczego określeniu kompetencji Zgromadzenia. Powodem było to, że „Obrady i uchwały Zgromadzenia Narodowego, a przede wszystkim jego komisji, przekroczyły pod kilkoma względami zwyczajowe granice i zadania każdego sejmu ustawodawczego" ${ }^{36}$. Negatywna odpowiedź Františka Weyra przewodniczącego komisji konstytucyjnej, nadeszła 6 lutego 1919 r.: „Niezaprzeczalne i też niekwestionowane we wniosku prawo obecnego Zgromadzenia Narodowego do nadania państwu pierwszej konstytucji, z której wszelki porządek prawny będzie wywodził swoją moc prawną, jest tak wielkie $\mathrm{i}$ istotne, że w porównaniu $\mathrm{z}$ nim schodzą na dalszy plan wszelkie pozostałe jego kompetencje, które w projekcie zasadniczo chce się ograniczyć. Nie jest zatem ani teoretycznie możliwe, ani w praktyce zalecane podejmowanie próby zasadniczego określenia kompetencji prawodawczych obecnego Zgromadzenia Narodowego, ponieważ kwestia, czy to Zgromadzenie powinno lub czy może rozstrzygać dany wniosek ustawodawczy pochodzący albo od jego członków, albo od rządu nie jest materią konstytucyjno-prawną, ale jest raczej kwestią taktyki parlamentarnej i taktu politycznego wobec ludności" ${ }^{37}$.

Liczba członków rewolucyjnego Zgromadzenia Narodowego została wprawdzie określona na 256 osób, ale w praktyce liczyło ono 254 członków, przy czym byli to tylko Czesi i Słowacy. Nie było tam przedstawicieli narodowości niemieckiej ani węgierskiej. Liczba słowackich członków rewolucyjnego Zgromadzenia Narodowego proponowana przez V. Šrobára wynosiła 50 osób, a Fedor Houdek proponował od 50 do 80 osób. Ostatecznie Šrobár zadowolił się tymczasowym rozwiązaniem, czyli liczbą 40 osób, pod warunkiem, że później zostanie ona zwiększona ${ }^{38}$. Mniejszą liczbę słowackich mandatów uzasadniano brakiem czasu, problemami komunikacyjnymi oraz niespokojną sytuacją na Słowacji. O tym, kto ze Słowaków wejdzie do praskiego parlamentu, decydował V. Šrobár bez porozumienia się z szerszym gremium. Kryteria jego wyboru nie odzwierciedlały rzeczywistego rozkładu sił politycznych na Słowacji. Šrobár preferował on osoby reprezentujące prąd liberalno-agrarny i socjaldemokratyczny, przez co zagwaran-

${ }^{35}$ Národni shromáždění československé v prvním roce republiky, Praha: Předsednictvo Národního Shromáždění, 1919, s. 218.

36 Zasedání Národního shromáždění československého r. 1918, tlač 209. Návrh předsedy českoslov. strany lidové prof. Jana Šrámka a soudruhů, aby zásadně vymezena byla činnost nynějšího Národního shromáždění; vide $<$ https://www.psp.cz> .

${ }^{37}$ Zasedání Národního shromáždění československého r. 1919, tlač 484. Zpráva ústavního výboru o návrhu prof. Jana Šrámka a soudr., aby zásadně vymezena byla činnost nynějšího Národního shromáždění.

${ }^{38}$ J. Kuklík, Př́prava a príietí prozatímni ústavy, [w:] Československá ústava 1920, red. E. Broklová, Praha 2010, s. 83-84. 
tował też konformistyczne stanowisko Zgromadzenia wobec kwestii czecho-słowackiej jedności narodowej. Sztucznie zmniejszył liczbę posłów konserwatywnych z SNS oraz z katolickiej Słowackiej Partii Ludowej (Slovenská l’udová strana). Te działania Šrobára wywołały zastrzeżenia ze strony Komitetu Wykonawczego SNR ${ }^{39}$. Oprócz Słowaków miejsca w Klubie Posłów Słowackich tymczasowo otrzymali też Czesi, którzy wcześniej byli członkami Komitetu Słowackiego w NVČS (J. Záruba-Pfeffermann, J. Rotnágl, A. Kolísek, R. Pilát). Dołączyli do nich: J. Vlček, E. Beneš, Alice Masaryková (córka T.G. Masaryka), F. Benda, I. Hálek, J. Cholek, F. Votruba ${ }^{40}$. Liczba posłów słowackich w rewolucyjnym Zgromadzeniu Narodowym wzrosła o 14 osób na wniosek strony słowackiej w wyniku nowelizacji tymczasowej konstytucji ustawą nr 138/1919 z 11 marca 1919 r. Łączna liczba posłów po tej zmianie wzrosła do 270 . W tymczasowym Zgromadzeniu Narodowym posłowie zostali podzieleni na siedem klubów partyjnych: partii agrarnej (55 osób, przewodniczący A. Švehla), partii socjalistycznej (29 osób, przewodniczący B. Vrbenský), partii socjaldemokratycznej (53 osoby, od marca 1919 r. 55 osób, przewodniczący R. Bechyně), partii narodowodemokratycznej (46 osób, przewodniczący F. Lukavský), partii ludowej (24 osoby, przewodniczący J. Šrámek), partii postępowej (6 osób, przewodniczący F. Veselý) oraz klub posłów słowackich (40 osób, od marca 1919 r. 54 członków, przewodniczący F. Houdek). Kluby miały własne posiedzenia i rozmawiały o sprawach politycznych. Ich przewodniczący spotykali się na wspólnych naradach. W rewolucyjnym Zgromadzeniu Narodowym powstawały też komisje. Łącznie do 28 maja 1919 r. funkcjonowało ich aż 35, wiele z nich pracowało nad bardzo wąskimi i pragmatycznymi zagadnieniami. Wśród przewodniczących komisji było tylko czterech Słowaków ${ }^{41}$. Ciekawostką jest to, że po raz pierwszy w ławach poselskich zasiadły też posłanki, których było osiem ${ }^{42}$.

39 J. Rychlík, Ústava ČSR z r. 1920 - historické souvislosti, [w:] Československá ústava 1920, red. E. Broklová, Praha 2010, s. 50; Dokumenty slovenskej národnej identity a štátnosti II, red. M. Pekník, Bratislava 1998, s. 53-55.

${ }^{40}$ I. Tichý, Vznik a personálne zloženie Klubu slovenských poslancov (1918-1920), ,Slovenská Archivistika" 1997, nr 2, s. 92-93.

41 Były to następujące komisje: do spraw zbadania zarekwirowanego tajnego archiwum policji (przewodniczący K. Dědic), obrony (F. Udržal), finansów (C. Horáček), ds. immunitetu (M. Dula), ds. zmiany porządku obrad (R. Rohlíček), kolonizacji wewnętrznej (A. Prokůpek), kultury (J. Herben), ds. mniejszości i wytyczenia granic (F. Lukavský), pokojowa (F. Udržal), gospodarki narodowej (V. Paulíny), ochrony zabytków historycznych i piękna przyrody (A. Jirásek), ds. petycji (K. Jonáš), ubezpieczeniowa (J. Hucl), pocztowa (J. Kadlčák), ds. reformy rolnej (A. Prokůpek), prawna (J. Matoušek), budżetowa (J. Kadlčák), spraw słowackich (M. Dula), polityki społecznej (V. Johanis), pracowników państwowych (G. Navrátil), szkolnictwa (O. Srdínko), techniczna (B. Bečka), konstytucyjna (A. Meissner), ds. ukarania zbrodniarzy wojennych (J. Svozil), ds. Wielkiej Pragi (E. Špatný), gospodarki wodnej (K. Sontág), ds. dodatków żywnościowych (L. Aust), spraw zagranicznych (M. Hodža), zaopatrzenia (J. Šamalík), zdrowia (L. Aust), rolnictwa (L. Okánik), ds. kolei (F. Buříval), rzemiosła (J. Slavíček), ds. odpowiedzi na przesłanie prezydenta państwa (A. Svěcený), ds. sytuacji ekonomicznej i socjalnej legionistów i ich rodzin (A. Slavík). Národní shromáždění československé v prvním roce republiky, Praha 1919, s. 62.

${ }^{42}$ Národni shromážděni republiky Československé v prvém desitiletí, Praha 1928, s. 18. 


\section{KWESTIA SLOWACKA}

Słowacy przychodzili do parlamentu bez wcześniejszych doświadczeń parlamentarnych. W odróżnieniu od większości czeskich posłów, którzy pracowali w parlamencie austriackim, tylko dwie osoby: F. Juriga i P. Blaha miały już doświadczenie z pracy w parlamencie węgierskim. Tę różnicę udało się stopniowo zniwelować, ale spowodowała ona wiele szkód, jeśli chodzi o forsowanie interesów Słowacji w nowym państwie. Posłowie słowaccy utworzyli w praskim parlamencie Klub Słowacki, bez różnicy orientacji politycznej. Jego celem była obrona interesów politycznych, kulturalnych i społecznych Słowacji w Zgromadzeniu Narodowym i poza nim ${ }^{43}$. Klub od 28 listopada 1918 r. miał własny statut i jego członkowie w zasadniczych kwestiach głosowali tak samo. Utrzymanie Klubu Słowackiego jako odrębnego ciała w Zgromadzeniu Narodowym było z pewnego punktu widzenia korzystne podczas forsowania słowackich interesów, ale w perspektywie długoterminowej było nie do utrzymania wskutek dużych różnic między partiami politycznymi. Dlatego klub istniał tylko do pierwszych wyborów parlamentarnych w $1920 \mathrm{r}$.

Kwestia przyłączenia Słowacji, która przed 1918 r. stanowiła część Węgier, do ČSR należała do najbardziej skomplikowanych zagadnień, jakimi musiały się zająć NVČS i rewolucyjne Zgromadzenie Narodowe. Jeszcze NVČS 2 listopada 1918 na wniosek V. Šrobára podjął decyzję o okupacji wojskowej Słowacji. Dwa dni później wysłał on na Słowację swoich pełnomocników: V. Šrobára, P. Blahę, I. Dérera i A. Štefánka, aby wykonali to zadanie. 5 listopada 1918 r. pełnomocnicy utworzyli w Hodonínie rząd tymczasowy i rozdzielili funkcje. Premierem został V. Šrobár, który tytułował się ,tymczasowym premierem tymczasowego rządu na Słowacji”. Doszło do tego bez wiedzy SNR w Martinie i były to kroki nieprzemyślane. Na zgromadzeniu ludowym, które zorganizowano po przyjeździe Rządu Tymczasowego do Skalicy 6 listopada 1918 r., oświadczyli oni, że państwo czecho-słowackie przejmuje rządy na Słowacji. Kompetencje tymczasowego rządu ze Skalicy były ograniczone do regionu Záhoria i jego największym, ale krótkotrwałym sukcesem było zajęcie Trnavy 7 listopada 1918 r. ${ }^{44}$ Po ataku wojsk węgierskich 13 listopada Trnava jednak upadła i później ponownie musiało zająć ją wojsko. Po tych doświadczeniach Rada Ministrów w Pradze postanowiła 7 grudnia 1918 r. mianować V. Šrobára ministrem pełnomocnikiem ds. Słowacji. Šrobár otrzymał pełnomocnictwa w zakresie utrzymania porząd$\mathrm{ku}$, konsolidacji sytuacji oraz zapewnienia funkcjonowania nowego państwa czech-słowackiego na Słowacji. Projekt ustawy o nadzwyczajnych i przejściowych środkach na Słowacji, w której określono najważniejsze zasady funkcjonowania Słowacji w ramach ČSR, przyjęło rewolucyjne Zgromadzenie Narodowe 10 grudnia 1918 r. jako ustawę nr 64/1918. Przyznawano w niej rządowi prawo do udzielenia pełnomocnictwa swojemu członkowi w zakresie wydawania rozporządzeń w celu zapewnienia porządku

\footnotetext{
${ }^{43}$ Zápisnice Klubu slovenských poslancov I, red. N. Petranská Rolková, Bratislava, 2014, s. 31.

${ }^{44}$ M. Hronský, A. Krivá, M. Čaplovič, Vojenské dejiny Slovenska 1914-1939, t. 4, Bratislava 1996, s. 96-97.
} 
i konsolidacji sytuacji na Słowacji. Aby mogły one wejść w życie, wystarczył tylko podpis ministra pełnomocnika ds. Słowacji. Ustawą rozwiązywano też wszystkie komitety miejskie i gminne, przy czym ich kompetencje przeszły na komisje ustanowione przez ministra pełnomocnika. Dostojnicy, urzędnicy i pracownicy państwowi, samorządowi i kościelni byłego Królestwa Węgierskiego tymczasowo zachowali swoje urzędy. Warunkiem było złożenie przysięgi na wierność ČSR, a także opinia ministra pełnomocnika, który mógł zdecydować o tym, czy mogą oni odpowiedzialnie realizować wyznaczone zadania. Wskazano, że na Słowacji językiem urzędowym jest słowacki, przy czym stosowanie innych języków miało zostać uregulowane w odrębnym rozporządzeniu. Miano kontrolować kupno i sprzedaż nieruchomości, transfery większych kwot finansowych oraz zawieranie umów handlowych i wywożenie artykułów żywnościowych ze Słowacji poza terytorium ČSR. Zakazano wywozu dzieł sztuki, archiwów i bibliotek ze Słowacji. Zarządzanie majątkiem i przedsiębiorstwami państwowymi przejęły centralne ministerstwa w Pradze. Rewizji podlegały wszystkie przyznane prawa w zakresie wyszynku i sprzedaży napojów alkoholowych, dodatkowo ustawą zakazano podawania napojów alkoholowych z wyjątkiem piwa i wina ${ }^{45}$. Šrobár dostał do dyspozycji 14 referentów, którzy formalnie zostali przydzieleni do poszczególnych ministerstw. Podczas prac nad ustawą w parlamencie wystąpił premier Kramár̆, który zwrócił uwagę na to, że ministerstwo ma status przejściowy. Šrobár z praktycznych powodów na swoją siedzibę wybrał Żylinę w północnozachodniej Słowacji, blisko granicy z Czechami.

Rozpoczęło się systematyczne zajmowanie Słowacji przez armię czecho-słowacką przy wsparciu ochotników. Šrobár nie docenił potencjału słowackiego katolicyzmu politycznego i wskutek pozbawionego wrażliwości podejścia przy podziale funkcjipolitycznych oraz w kwestii oświaty uczynił z niego twardą opozycję. Przyspieszył w ten sposób powstanie słowackiego ruchu autonomistycznego, który stał się najsilniejszą opozycyjną siłą polityczną na Słowacji w ČSR. W ramach pełnionej przez siebie funkcji ministra pełnomocnika 8 stycznia 1919 r. wydał rozporządzenie nr 6/1918, na podstawie którego od 23 stycznia 1919 r. zostały zlikwidowane wszystkie lokalne słowackie rady narodowe, w tym też centralna SNR w Martinie ${ }^{46}$. Šrobár ostatecznie przeniósł się wraz ze swoim ministerstwem do Bratysławy 4 lutego 1919 r. Rewolucyjne Zgromadzenie Narodowe i pierwszy rząd ČSR musiały sobie poradzić nie tylko z włączeniem Słowacji do nowego państwa, gdzie na południu żyła liczna mniejszość węgierska, ale też z zajęciem terytorium zamieszkiwanego przez mniejszość niemiecką, która do nowego państwa nie chciała przynależeć, oraz z przyłączeniem spornego Śląska Cieszyńskiego, w sprawie którego też toczył się spór. Ta kwestia musiała zostać rozwiązana na poziomie międzynarodowym w $1920 \mathrm{r}$.

45 Zákon č. 64 ze dne 10.12.1918 o mimořádných přechodních ustanoveních na Slovensku, „Sbírka Zákonů a Nařízení Státu Československého" 1918, nr 13, s. 13.

${ }^{46}$ M. Hronský, Slovensko pri zrode Československa..., s. 321. 


\section{PODSUMOWANIE}

Parlamentaryzm ČSR nawiązywał do miejscowych tradycji parlamentaryzmu austro-węgierskiego, ale przede wszystkim czerpał inspiracje z ustrojów parlamentarnych demokracji zagranicznych, zwłaszcza Francji i USA. Droga do czecho-słowackiego parlamentaryzmu wymagała stworzenia odpowiednich warunków, co nastąpiło pod koniec I wojny światowej. Punktem kulminacyjnym było rewolucyjne powstanie państwa. Początki czecho-słowackiego parlamentaryzmu sięgają NVČS, który 28 października 1918 r. przekształcił się w rewolucyjny organ skupiający władzę ustawodawczą i wykonawczą. Rewolucyjne Zgromadzenie Narodowe rozpoczęło swoją działalność 14 listopada 1918 r., przy czym została od niego oddzielona władza wykonawcza w formie rządu. Zgromadzenie zachowało swój rewolucyjny i tymczasowy charakter i jednocześnie stało się ustawodawczym Zgromadzeniem Narodowym. Punktem kulminacyjnym jego działalności było przyjęcie konstytucji (ustawa nr 121/1920 z 29 lutego 1920 r.). Rewolucyjne Zgromadzenie Narodowe formalnie zakończyło swoją działalność 15 kwietnia 1920 r., omówiło i przyjęło na komisjach i na posiedzeniach plenarnych 393 ustawy. Ta intensywna działalność wynikała z chęci rozwiązania problemów, które niosły ze sobą wojna oraz budowanie nowego porządku prawnego i nowej funkcjonalnej organizacji państwowej opierającej się na zasadach demokracji, która w pełni odpowiadałaby potrzebom socjalnym, gospodarczym, kulturalnym i obronnym nowego państwa. Udało się wówczas przyjąć wiele nowoczesnych ustaw, stworzyć podstawowe instytucje państwowe, własną walutę, armię, zapewnić bezpieczeństwo, wymiar sprawiedliwości, a także stworzyć nowoczesne instytucje kulturalne i oświatowe, nowoczesne ustawodawstwo socjalne wraz z ubezpieczeniem społecznym, ośmiogodzinnym dniem pracy i wsparciem dla bezrobotnych, a także fundamenty reformy rolnej.

\section{BIBLIOGRAFIA}

ŹRÓDŁA

Dokumenty slovenskej národnej identity a štátnosti II, red. M. Pekník, NLC, Bratislava 1998.

Országgyülés képviselőházának naplója. XXXVI. kötét. 726. országos ülés 1917 június 21-én, csütörtökön. Hiteles kiadás, Budapest 1917.

Országgyülés képviselőházának naplója, XLI. kötét. 826. országos ülés 1918 október 19-én, szombaton. Budapest: Hiteles kiadás, 1918.

Stenographisches Protokoll. Haus der Abgeordneten. XXII. Session. 1. (Eröffnungs-) Sitzung. Mittwoch, den 30. Mai 1917.

Stenographisches Protokoll. Haus der Abgeordneten. 85 Sitzung der XXII. Session am 2. Oktober 1918.

Stenographisches Protokoll. Haus der Abgeordneten. 92 Sitzung der XXII. Session am 22. Oktober 1918.

Zápisnice Klubu slovenských poslancov I, red. Petranská-Rolková N, Národná rada Slovenskej republiky, Bratislava 2014.

Pr a s a

„Lidové noviny” 1918.

„Národní listy” 1918. 
„Naše revoluce” 1932.

„Rozvoj” 1924.

Společná česko-slovenská digitální parlamentní knihovna, https://www.psp.cz/eknih.

PIŚMIENNICTWO

Monografie

Broklová E., Československá ústava 1920, Centrum Pro Ekonomiku a Politiku, Praha 2010.

Galandauer J., Vznik Československé republiky 1918, Svoboda, Praha 1988.

Hronský M., Slovensko pri zrode Československa, Pravda, Bratislava 1987.

Hronský M., Krivá A., Čaplovič M., Vojenské dejiny Slovenska 1914-1939, zv. 4., MNO, Bratislava 1996.

Hronský M., Pekník M., Martinská deklarácia. Cesta slovenskej politiky k vzniku Česko-Slovenska, VEDA, Bratislava 2008.

Klimek A., Říjen 1918. Vznik Československa, Paseka, Praha 1998.

Kvaček R., První světová válka a česká otázka, Triton, Praha 2013.

Národní shromáždění československé v prvním roce republiky, Předsednictvo Národního Shromáždění, Praha 1919.

Peroutka F., Budování státu, zv. 1-5, F. Borový, Praha 1933-1936.

Peša V., Vznik Československé republiky 1918 a české národni výbory, Horizont, Praha 1988.

Rieder H., Kaiser Karl, Callwey Verlag, München 1981.

Soukup F., 28. řijen 1918, zv. 1, 2, Orbis, Praha 1928.

A rtykuły

Kuklík J., Př́prava a prijietí prozatímní ústavy, [w:] Československá ústava 1920, red. E. Broklová, Centrum Pro Ekonomiku a Politiku, Praha 2010.

Rychlík J., Ústava ČSR z r. 1920 - historické souvislosti, [w:] Československá ústava 1920, red. E. Broklová, Centrum Pro Ekonomiku a Politiku, Praha 2010.

Tichý I., Vznik a personálne zloženie Klubu slovenských poslancov (1918-1920), „Slovenská archivistika" 1997, nr 2.

W s p o m ni e n i a

Hajšman J., Mafie v rozmachu, Orbis, Praha 1933.

Paměti Dr. Aloise Rašína, red. Rašín A., Bonus, Brno 1994.

Rotnágl J., Češi a Slováci. Vzpomínky a úvahy nad dopisy a zápisniky z let 1907-1918, J.R. Vilímek, Praha 1945.

Šrobár V., Osvobodené Slovensko. Pamäti z rokov 1918-1920, zv. 1, ČIN, Praha 1928. 